\title{
A photographic technique for assessing the pasture species performance of grazing animals
}

\author{
W.F. Hunt and J.M. Hay \\ Grasslands DSIR, \\ Private Bag, Palmerston North
}

ABSTRACT Four replicates of each of 16 grasses, herbs and legumes were sown on a thoroughbred stud and a deer farm in the Waikato. Grazing stock (horses, deer or calves) were introduced to the plots and their preferences recorded using 4 automatic winding, infrared, remote-triggering cameras, mounted on poles $3 \mathrm{~m}$ high. Distinct differences in preferences were identified among horses, deer and calves. 'Grasslands Matua' was most preferred with horses spending twice as much time grazing Matua plots as most other grasses. Italian and tetraploid ryegrasses were the next most frequently grazed. Deer showed a clear preference for legumes and herbs, particularly low oestrogen red clover, and calves showed a clear preference for grasses other than ryegrass. The novel photographic technique establishes a reliable method of obtaining a permanent record of grazing animal preferences to pure swards of a range of pasture species. Information on the species preferences of different classes of stock provides the starting point for alternative species to ryegrass and white clover when developing the total farm management system.

K eywords pasture species, deer, horses, calves, preference, photographic technique

\section{NTRODUCTION}

A dramatic feature of the New Zealand pastoral scene during the last decade has been the diversification in the animal species with which farms are stocked. The sheep, cattle and occasional horse farms have had to make room for new exotic cattle breeds, red, fallow, and wapiti deer, angora and cashmere goats, the odd alpaca, and the rumour of water buffalo. All these species have been simply put out on existing pasture, which was predominantly ryegrass and white clover.

Perennial ryegrass is preferred by farmers for its relative persistence and productivity on many soil types and in many climes. Another major advantage is the ease with which ryegrass pastures establish and the relatively wide range of conditions under which seeds will germinate. This reliability has established perennial ryegrass as the standard pasture grass, and this status has been reflected in research investment (Hunt \& Easton 1989). However, it is not clear that ryegrass is the most preferred species by all classes of stock. As pasture species comprise the base of any pastoral industry, it may be prudent to be aware of animal preferences as types of stock diversify.

Pasture species preferences by sheep and cattle have in the past been considered important to the full utilisation and stability of pasture (Ivins 1955), and have been judged influential on animal intake (Tribe \& Gordon 1950).

\section{METHODS}

Research plots were established on a commercial deer and dairy beef farm at Wardville, Matamata to determine pasture species preferences by deer and Friesian calves. Similar plots were also established on an equine stud farm at Walton, Matamata. Four replicates of each of 16 grasses, herbs and legumes (Table 1) were sown on these properties in autumn 1988. Plots $(7 \times 7 \mathrm{~m})$ were arranged in an 8 by 8 grid, each replicate block of 16 plots occupying one quarter of the grid. There were minor variations in the cultivars (two) and species (two) between the two sites (Table 1).

\section{Photographic technique}

When plots were, on average, $15 \mathrm{~cm}$ in height, stock were introduced and their preferences recorded using 4 automatic winding, infrared, remote-triggering cameras, mounted on poles $3 \mathrm{~m}$ high. Each camera sighted 4 treatment lanes, with 2 cameras on each of 2 adjacent sides of the grid. Thus the plots grazed by stock for any sampling photo-frame could be identified through crossreferencing the lanes occupied by the stock as viewed from each adjacent side.

Each roll of 36 frames results in a 'run' 72 minutes long when frames are taken at 2-minute intervals. Typically, 3 'runs' are taken during a day, resulting in 432 photographs for analysis.

\section{RESULTS \\ Deer}

The pasture species tested fell into 4 clear preference groups (Figure 1, Table 1). The low oestrogen red clover was preferred twice as much as any other species, with lotus, chicory, white clover, and sheep's bumet being preferred next. The remaining legumes, lucerne, sainfoin and sulla, were preferred above any of the grasses or dock. 
Figure 1 Grazing preferences of lactating red deer hinds in the Waikato during summer, cumulative totals for 3 runs.

Figure 2 Grazing preferences of Friesian calves in the Waikato during autumn, cumulative totals for 3 runs.

Figure 3 crazing preferences of mares in the Waikato during autumn, cumulative totals for 3 runs.
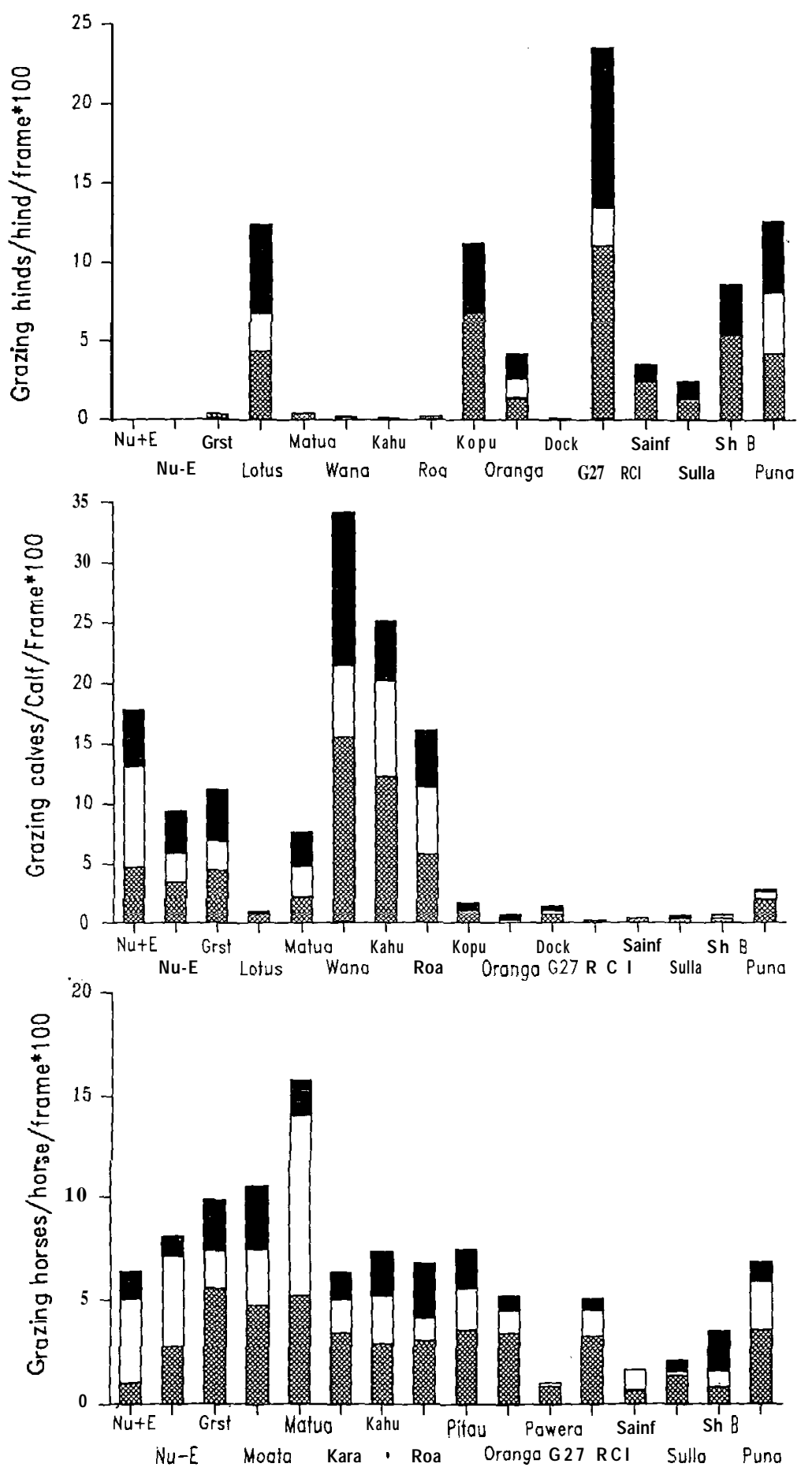

Calves

$\mathrm{Th}$ e pasture species tested again fell into 4 preference groups (Figure 2, Table 1). Cocksfoot was clearly preferred over other species, with timothy, tall fescue and high endophyte perennial ryegrass preferred next. The remaining grasses, 
prairie grass, hybrid ryegrass, and low endophyte perennial ryegrass, were preferred above all legumes and herbs.

Comparison of the 3 runs (Figure 4b) showed them to be consistent despite the runs being made at different times of the day, apart from a relatively low preference for Wana during run 2.

\section{Horses}

The pasture species tested fell into 3 preference groups (Figure 3, Table 1). Prairie grass was preferred over $50 \%$ more than the next preferred species. All other species were acceptable to horses, apart from the high oestrogen red clover, sainfoin, sulla, and sheep's burnet.

Comparison of the 3 runs (Figure $4 \mathrm{c}$ ) showed a decline in grazing activity for run 3 (in the late afternoon) compared with runs 1 and 2 . The strong preference for Matua in run 2 was not detected during run 3. During the first run, preference was strongest for Greenstone, Moata, and Matua.

\section{DISCUSSION}

Continuous observation was considered by Ivins (1955) the ideal for assessing palatability, but human observers are unreliable recorders of detail. The photograhic technique we have developed here simply provides a way for the observer to study stock activity for an instant in time for as long as is needed to accurately analyse the detail. The main advantages are hence:

(a) Rapid error-free sampling Taking photographic frames at designated intervals provides a permanent and direct measure of what the stock are eating for as long as photos are taken.

(b) Reliability Species preferences revealed by the technique at any one site are consistent when different 'runs' are compared (Figure 4). Indirect methods such as before and after grazing yield comparisons have too many errors associated with them. For example, when we correlated before and after capacitance probe readings (Hunt \& Hay

Table I Pasture species preferences by three classes of stock in the Waikato.

\begin{tabular}{|c|c|c|c|c|}
\hline & & $\begin{array}{l}\text { Order o } \\
\text { Hinds }\end{array}$ & $\begin{array}{l}\text { preference } \\
\text { Calves }\end{array}$ & Horses \\
\hline I & $\begin{array}{l}\text { High endophyte 'Grasslands Nui' ryegrass } \\
\text { (Lolium perenne L.) }\end{array}$ & $15=$ & 3 & 9 \\
\hline 2 & $\begin{array}{l}\text { Low endophyte 'Grasslands Nui' ryegrass } \\
\text { (Lolium perenne L.) }\end{array}$ & $15=$ & 6 & 4 \\
\hline 3 & $\begin{array}{l}\text { 'Grasslands Greenstone' ryegrass } \\
\text { (Lolium } x \text { hybridum Hausskn.) }\end{array}$ & 10 & 5 & 3 \\
\hline 4 & $\begin{array}{l}\text { 'Grasslands Moata' ryegrass } \\
\text { (Lolium multiflorum Lam.) }\end{array}$ & $\rightarrow$ & & 2 \\
\hline 5 & $\begin{array}{l}\text { 'Grasslands Kara' cocksfoot } \\
\text { (Dactylis glomerata L.) }\end{array}$ & - & & 10 \\
\hline 6 & $\begin{array}{l}\text { "Grasslands Wana" cocksfoot } \\
\text { (Dactylis glomerata L.) }\end{array}$ & I I & 1 & \\
\hline 7 & $\begin{array}{l}\text { 'Grasslands Matua' prairie grass } \\
\text { (Bromus willdenowii Kunth) }\end{array}$ & 9 & 1 & 1 \\
\hline 8 & $\begin{array}{l}\text { 'Grassiands Kahu' timothy } \\
\text { (Phleum pratense L.) }\end{array}$ & $13=$ & 2 & 6 \\
\hline 9 & $\begin{array}{l}\text { 'Grasslands Roa' tall fescue } \\
\text { (Festuca arundinacea Schreb.) }\end{array}$ & 12 & 4 & 1 \\
\hline 10 & $\begin{array}{l}\text { 'Grasslands G27' low oestrogen red clover } \\
\text { (Trifolium pratense' L.) }\end{array}$ & & 16 & $\mathrm{I} 2$ \\
\hline 11 & $\begin{array}{l}\text { 'Grasslands Pawera red clover } \\
\text { (Trifolium pratense L.) }\end{array}$ & - & & 16 \\
\hline 12 & $\begin{array}{l}\text { 'Grasslands G32' lotus } \\
\text { (Lotus corniculatus L.) }\end{array}$ & 2 & II & \\
\hline 13 & $\begin{array}{l}\text { 'Grasslands Oranga' luceme } \\
\text { (Medicago sativa L. ) }\end{array}$ & 6 & 13 & 11 \\
\hline 14 & $\begin{array}{l}\text { 'Grasslands Kopu' white clover } \\
\text { (Trifolium repens L.) }\end{array}$ & 4 & 9 & \\
\hline 15 & $\begin{array}{l}\text { 'Grasslands Pitau' white clover } \\
\text { (Trifolium repens L.) }\end{array}$ & & & 5 \\
\hline 16 & $\begin{array}{l}\text { 'Grasslands sainfoin' } \\
\text { (Onobrichis riciifolia Scop.) }\end{array}$ & & 15 & 15 \\
\hline 17 & $\begin{array}{l}\text { Aokau sulla } \\
\text { (Hedisarum coronarium ) }\end{array}$ & 8 & 14 & 14 \\
\hline IX & $\begin{array}{l}\text { "Grasslands Puna chicory } \\
\text { (Cichorium int bus) }\end{array}$ & 3 & 8 & 8 \\
\hline 19 & $\begin{array}{l}\text { Sheep's bumet } \\
\text { (Sunguisurba minor) }\end{array}$ & 5 & I2 & 13 \\
\hline 20 & $\begin{array}{l}\text { "Common dock' } \\
\text { (Rumex obrusitolius L.) }\end{array}$ & $13=$ & 10 & \\
\hline
\end{tabular}



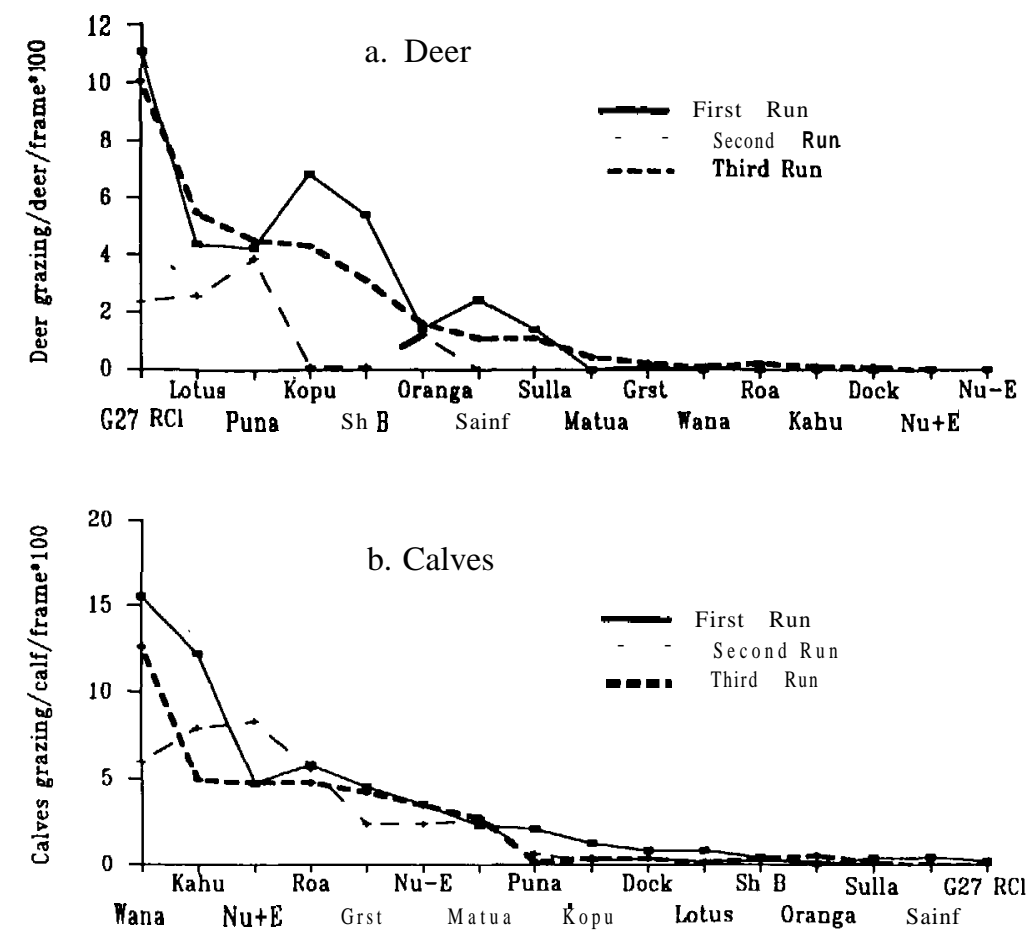

Figure 4 A comparison of grazing preferences sequences in three runs for deer. calves and mares in the Waikato during autumn.

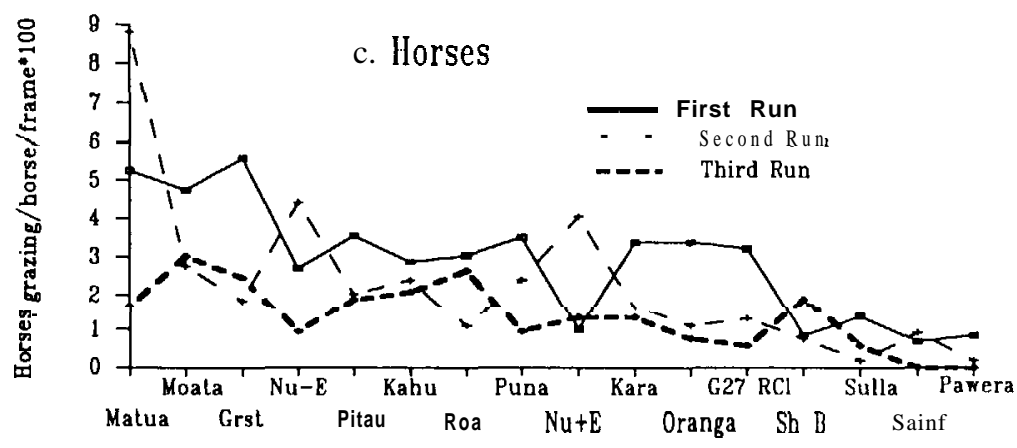

unpublished) with observed grazing from photographs, there was no correlation $(\mathrm{r}=0.27 \mathrm{~ns}$ ) because herbage removal was light. This emphasises the importance of direct measurement techniques, despite an inclination by many researchers for indirect pasture measurement methods (Ivins 1955). '

(c) Sequences in preference are detectable Past techniques for determining species preference have suffered from an inability to detect sequences in animal grazing. The photographic technique, by providing a continuous records, enables the stage at which stock have removed sufficient of the most preferred species to cause them to move on to less preferred species to be identified. For example, the proportion of mares grazing Matua was greatly reduced in run 3 after 2-3 hours of grazing compared with runs 1 and 2 (Figure 4c). (d) All stock activities can be analysed The photographic technique provides data on all horse activities including walking, eating, lying down and loafing times.

The only problems experienced with the technique are those common to photography. Wet weather caused fogging of lenses unless lens filters were removed. One plot remained outside camera view (and was monitored visually) despite using wide-angle (35") lenses and siting cameras $10 \mathrm{~m}$ back from the plot edge. The technique is limited to daylight hours, but could possibly be extended to night time using infra-red film.

The results (Figures 1 to 3 ) show clearly that horses, calves and deer will exercise relatively strong grazing preferences when given a choice, and that differences between the classes of stock in their 
preferences arc also marked. For example, Table 1 and Figure 4 show the order of preference for deer is approximately the inverse of the order of preference for calves.

Comparison of our results with published work is difficult because of the many confounded factors that can affect palatability (Marten 1978), and because of the paucity of palatability studies in New Zealand. It must be remembered that data presented here are limited to the spring and summer seasons.

The horse data (Figure 3) agree with those of Archer (1973) in that ryegrasses were palatable, but Archer did not test prairie grass or Italian ryegrass (the most preferred in Figure 3), and we did not test creeping red fescue, the most palatable species tested by Archer ( 1978). The horse's preference for prairie grass follows observations which go back to the 19th century (Way 18.53 ).

The results in Figure 2 expressing a strong preference by calves for Wana cocksfoot has little in common with data of Ivins ( 1952), in which Danish cocksfoot and S. 143 cocksfoot are ranked relatively low.

The strong preference by deer for legumes and herbs over grasses explains the weed free "grassy" look of deer farms. While this look may be pleasant to the farmer's eye, it probably looks like a desert to the deer, but more importantly the lack of legume content could have severe consequences for future pasture production if nitrogen levels are not replenished.

If deer have to be forced to eat ryegrass, what levels of production might be possible with highly palatable, highly nutritious, and highly summer productive species such as low oestrogen red clover? It has been established (Tribe \& Gordon 1950) that palatability affects the quantity of feed ingested, and they inferred from the evidence of Brody ( 1945) that animal productivity could be increased through the use of the most palatable pasture species, provided they are of high nutritional value.

Attention to determining species preferences has declined in recent years perhaps because preferences are considered less important than they once were in determining DM intake (Ivins 1955). It is assumed current management techniques aimed at high untilisation leave stock with little choice in diet selection. However, Clark et al. (1982) found that although sheep with oesophageal fistulas did not select for white clover, they selected strongly for the green grass component, and strongly against dead material.
Our data suggest that there will be certain long term consequences to sward stability if species preferences are ignored. Some of these consequences are apparent but little understood. The difficulties in maintaining permanent weed-free evenly grazed horse pastures on studs result from selective grazing by the horses which are not forced to utilise all pasture. Perhaps utilisation could be improved through using highly palatable species.

This work leads us to conclude that changes in farm enterprises involving alternative types of stock, should also consider changes to pasture type. Hence, information on the species preferences of different classes of stock provides the starting point for alternative species to ryegrass and white clover when developing the total farm management system.

Acknowledgements We gratefully acknowledge financial support from the New Zealand Equine Research Foundation, and from the Waikato and Hamilton Branches of the New Zealand Deer Fanner's Association. We would also like to thank Mr Mark Wilson, Evergreen Lodge Stud, and Mr Joe Minkhorst, Wardville for the use of their farms, and their continuing help and support in the running of these trials.

\section{REFERENCES}

Archer, M. 1973. The species preferences of grazing horses. Journal of the British Grassland Socieny 28: 123128.

Archer, M. 1978. Further studies on palatability of grasses to horses. Joumal of the British Grassland Society 33: 239.342 .

Brody, S. 1945. Bioenergctics and growth. Reinhold Publishing Co., New York.

Clark, D.A.: Lambert, M.G.; Chapman. D.F. 1982. Pasture Management and hill country production. Proceedings of the NZ Grassland Assocition 43: 205-2 14.

Hunt, W.F.: Easton, H.S. 1989. Fifty years of ryegrass research in New Zealand. Proceedings of the NZ Grassland Association 50: I I-23.

Ivins. J.D. 1952. The relative palatability of herbage plants. Journal of the British Grassland Society 7: 43-54.

Ivins, J.D. 1955. The palatability of herbage. Herbage abstracts 25: 75-79.

Marten. G.C. 1978. The animal-plant complex in forage palatability phenomena. Joumal of animal science 46: $1470-1477$

Tribe, D.E.; Gordon. J.G. 1950. An experimental study of palatability. Agricultural progress 2.5: 94- 10 I.

Way, J.T. 1853. On the relative nutritive and fattening properties of different natural and artificial grasses. Journal of the Roval Agricultural Society of England, First Series: 14 